\title{
THE OPTIONAL PROTOCOL TO THE INTERNATIONAL COVENANT ON ECONOMIC, SOCIAL AND CULTURAL RIGHTS: A NEW INSTRUMENT TO ADDRESS HUMAN RIGHTS VIOLATIONS ${ }^{1}$
}

PROTOCOLO FACULTATIVO AO PACTO INTERNACIONAL SOBRE DIREITOS ECONÔMICOS, SOCIAIS E CULTURAIS: UM NOVO INSTRUMENTO PARA ENFRENTAR VIOLAÇÕES A DIREITOS HUMANOS

Christian Courtis*

\begin{abstract}
The article discusses the adoption of the new Optional Protocol to the International Covenant on Economic, Social and Cultural Rights as a means to obtain redress for violations against economic, social and cultural rights in the international sphere - including its potential use for the consideration of the violation of extraterritorial obligations.
\end{abstract}

Keywords: Human rights. Social rights. Violations. Optinal protocol.
Resumo: O artigo discute a adoção do novo Protocolo Facultativo ao Pacto Internacional sobre os Direitos Econômicos, Sociais e Culturais como um meio de obter reparação por violações a direitos econômicos, sociais e culturais no âmbito internacional - inclusive a sua potencial utilização em casos de violação de obrigações extraterritoriais.

Palavras-chave: Direitos humanos. Direitos sociais. Violações. Protocolo facultativo.

\footnotetext{
" Doctor; Professor at University of Buenos Aires; High Commissioner Executive in Human Rights of United Nations Organization; Viamonte Street, 430, 1053, Buenos Aires, Argentina; ccourtis@ohchr.org

1 The views expressed in this article are personal and are not meant to represent the opinion of the Office.
} 


\section{International justiciability}

The 1948 Universal Declaration of Human Rights proclaims the interdependence, indivisibility and equal value of all human rights. However, the adoption, in 1966, of two different universal instruments, a Covenant on Civil and Political another Covenant on Economic, Social and Cultural Rights, paved the way for a differential treatment of both sets of human rights. A particularly telling example of this differential treatment was the original provision of a complaints procedure for violations of civil and political rights, while no such procedure was established regarding economic, social and cultural rights.

On 10 December 2008, the adoption of a new international instrument, the Optional Protocol to the International Covenant on Economic, Social and Cultural Rights (OP-ICESCR $)^{2}$ has closed that legal protection gap, finally recognizing the justiciability of economic, social and cultural rights in the international sphere, on an equal footing with civil and political rights. It took the international community a long time to reach this stage. Early initiatives in the 1990s gathered little support, and only after intensive discussion in the context of a UN (United Nations) Open-ended Working Group, from 2003 to 2008, member States of the United Nations agreed to adopt the OP-ICESCR by consensus. ${ }^{3}$ Leading States, ${ }^{4}$ NGOs, treaty bodies, academic institutions and the Office of the UN High Commissioner for Human Rights were eventually successful in convincing the international community about the importance of providing access to international remedies in cases of alleged violations of economic, social and cultural rights.

\section{The main issues under discussion in the drafting of the OP-ICESCR}

The lack of an international complaints mechanism on economic, social and cultural rights has long given the impression that economic, social and cultural rights were different in nature from civil and political rights. Some still maintain that economic, social and cultural rights are not suitable for adjudication. They consider economic, social and cultural rights to be too vague to be justiciable and think that they should be seen as aspirations or policy goals, rather than as legal entitlements. They also argue that decisions regarding policy choices cannot be discussed in a judicial or quasi-judicial setting, but should rest with (democratic) political authorities. Others question the potential consequences of adjudication in the field of economic, social and cultural rights on the basis of the resource implications that judicial decisions may have.

\footnotetext{
2 Available at: <http://www2.ohchr.org/english/bodies/cescr/docs/A-RES-63-117.pdf>.

3 For a view of the history of the Working Group, <http://www2.ohchr.org/english/issues/escr/intro.htm >.

4 States which expressed strong views in favour of an OP-ICESCR included, within Europe, Portugal, Belgium, Finland and Spain, and generally the Latin American and African countries.
} 
In the course of the inter-governmental negotiations of the OP-ICESCR, the majority of States did not hold these views. In fact, they acknowledged the existence of a considerable comparative experience of judicial and quasi-judicial decisions in the area of economic, social and cultural rights, countering blanket assumptions against their justiciability.

The adoption of the OP-ICESCR may help to overcome such negative perceptions. It provides victims with international accountability mechanisms for addressing violations of this set of human rights, and allows the UN Committee on Economic, Social and Cultural Rights (CESCR), its monitoring body, an opportunity to refine the understanding of their content, through interpreting their scope in the context of specific cases.

The existence of an international complaints mechanism might also create an incentive to strengthen the protection of economic, social and cultural rights at the national level. Apart from requiring States parties to provide remedies in specific cases, case law at the international level can also provide guidance and promote jurisprudence at the national level. Furthermore, as the exhaustion of domestic remedies is a condition for the admissibility of complaints by CESCR, States might be urged to provide domestic remedies where these are non-existent or inadequate.

\section{The content of the OP-ICESCR}

The OP-ICESCR provides for three different mechanisms:

a) A procedure for communications (complaints), allowing individuals and groups of individuals to present complaints before the CESCR in case of alleged violation of one or more of the economic, social and cultural rights recognized in the ICESCR - such as labour rights, the right to social security, the right to health, the right to food, the right to housing, the right to education, the right to water or cultural rights.

b) An inter-State complaint mechanism, allowing a State party to submit communications to CESCR alleging that another State party is not fulfilling its obligations under the Covenant.

c) An inquiry procedure allowing CESCR to conduct an inquiry based on reliable information indicating grave or systematic violations of the ICESCR by a State Party.

The previous work of CESCR offers guidance about what can count as a violation of economic, social and cultural rights; several General Comments adopted 
by the Committee provide specific examples. ${ }^{5}$ For instance, violations of economic, social and cultural rights can occur when States interfere unduly with their enjoyment; when they fail to adopt steps towards their full realization; when they provide for or deny rights in a discriminatory manner; when they fail to comply with minimum core obligations (such as provision of essential medicines or ensuring universal, mandatory and free primary education); or adopt deliberately retrogressive measures without adequate justification. Violations also include failure to adopt measures to protect individuals against the impact of economic crises or globalization on their economic, social and cultural rights.

The procedure established by the OP-ICESCR is similar to other quasi-judicial communications mechanisms under the international human rights system. The practice of other treaty bodies regarding remedies is characterized by self-restraint: 'views' (jurisprudential decisions) usually recommend States to provide adequate remedies, but rarely prescribe such remedies in detail, leaving some leeway for the States concerned to come with a solution. Even if the ability to impose remedies is weak, the power of the treaty body to declare that a violation has occurred in a specific case is perhaps the most important feature of the communications mechanism. Committees usually follow up on the measures taken by States as a result of views through their subsequent dialogue with them.

The OP-ICESCR generally sticks to the model of the most recent UN instruments providing for communications mechanisms - such as the Optional Protocols to the Convention on the Elimination of Discrimination Against Women (CEDAW) and to the Convention on the Rights of Persons with Disabilities. But it also contains some new features. Most of these new features respond to two issues debated during the sessions of the Working Group: (1) whether the alleged 'different' nature of economic, social and cultural rights required procedural adjustments, and (2) whether the text should reflect the obligations of 'international cooperation and assistance' included in the several provisions of the ICESCR.

\subsection{Communications by individuals and groups of individuals}

(1) Communications can be submitted by or on behalf of individuals or groups of individuals, under the jurisdiction of a State Party, claiming to be victims of a violation against a State that has ratified the Optional Protocol. When communications are submitted on behalf of individuals and groups of individuals, their consent is required, unless the petitioner can justify acting on their behalf without such consent. In order for communications to be admissible, domestic remedies should be exhausted first, and the same fact should not be subject to similar international

5 For the latest list of the General Comments by CESCR, see <http://www2.ohchr.org/english/bodies/cescr/comments.htm>. 
procedures. The Committee can also declare a case inadmissible if it does not find that the alleged victims suffered a clear disadvantage, unless it considers that it raises an issue of general importance.

While the procedure is similar to other communications mechanisms provided by international human rights instruments, including the possibility of requesting interim measures, the OP-ICESCR incorporates some new features, such as the possibility for the Committee to accept a friendly settlement, and to consult a broader span of documentation emanating from other United Nations and regional agencies and bodies when considering communications. Some States also demanded that the OP-ICESCR clarified the standard of review to be employed by the Committee when considering communications. Consensus was reached to incorporate the standard of reasonableness to assess the steps taken by the State Party to realize the rights included in the Covenant, taking into account that the State Party may adopt a range of possible policy measures for complying with its duties.

\subsection{Inter-State communications}

The inter-State communications procedure allows States parties to the Protocol to submit complaints when they consider that another State Party is not fulfilling its obligations under the Covenant. Inter-State communications have been seldom employed under other Optional Protocols and equivalent instruments, as States prefer political fora to argue about alleged human rights violations committed by each other. In any case, the OP-ICESCR requires that States make an express declaration allowing for the use of inter-State communications - which might discourage the effectiveness of this potentially valuable procedure. ${ }^{6}$

\subsection{The inquiry procedure}

This procedure allows the Committee to initiate an inquiry when it receives reliable information indicating grave or systematic violations by a State Party of any of the economic, social and cultural rights set forth in the Covenant. ${ }^{7}$ Similar procedures have shown to be effective under the Convention against Torture and the Optional Protocol to CEDAW. However, while in those instruments the State needs to make a declaration not to be bound by the inquiry procedure, the OP-ICESCR requires the State to make an express declaration to be bound by the procedure.

${ }_{6}$ See comments on its potential use for extraterritorial obligations below.

7 Ibid. 


\subsection{International assistance and cooperation}

The OP-ICESCR has also incorporated provisions which acknowledge the legal dimensions of international assistance and cooperation:

a) Recommendations to UN entities: the Committee, with the consent of the State party concerned, may transmit its views and recommendations concerning communications and inquiries to United Nations agencies and other competent bodies, or to bring to their attention relevant matters arising out of communications, when it is apparent that there is a need for technical advice or assistance, or that international measures may contribute to assisting State parties in implementing the rights recognized in the Covenant.

b) Establishment of a trust fund: the OP provides for the establishment of a trust fund, with a view to providing expert and technical assistance for the enhanced implementation of the rights in the Covenant. The fund would be financed through voluntary contributions and needs to attract sufficient, regular funding to become operational. In the negotiation process, African countries pushed for the inclusion of such provision, while donor countries were generally skeptical about the justification of such fund.

\section{Extraterritorial obligations and the OP-ICESCR}

Even if the ICESCR does not make any reference to territorial or jurisdictional limits to its application, and in fact makes express reference to international assistance and cooperation as a legal obligation, the submission of communications under the OP-ICESCR is restricted to individuals or groups of individuals under the jurisdiction of the State party against which a violation of the ICESCR is alleged. 'Jurisdiction' is not necessarily confined to the territory of the State Party: CESCR has already indicated that a State party has jurisdiction beyond its own territory. The Committee has maintained that Covenant obligations apply to any territory over which a State party has geographical, functional or personal jurisdiction, including dependent territories ${ }^{8}$ and territories where a State has de facto control. ${ }^{9}$

However, the extent of the extraterritorial jurisdiction of States regarding economic, social and cultural rights is still being discussed under international law. Whether the human rights treaty extends to situations outside of the State's own territory and thus also affords those people its protection is a topical issue and arguably

CESCR, Concluding Observations the Netherlands E/1999/22 para. 194.

9 CESCR, Concluding Observations Israel E/1999/22 para. 232. 
there is no generally accepted presumption in favour of State jurisdiction beyond its own territory or the territories under its control (SALOMON; SEIDERMAN, 2012). Consequently, under the OP-ICESCR petitioners will bear the burden of proof in establishing that a violation occurring outside a State's territory falls within the State's jurisdiction.

The inter-State communication and the inquiry procedures might be more fitting for the consideration of extraterritorial violations of economic, social and cultural rights, as neither of them restricts the violations that could be examined by the Committee to the jurisdiction of the State party. Both mechanisms carry some limitations - they need to be opted in by the State party, and they do not entitle victims, but other State parties or in the case of the inquiry procedure the Committee, to initiate the procedure - but they might also have some advantages. For example, an inter-State communication brought by a State party against another State party for an extraterritorial violation can serve both to protect the sovereign interest of the former State and the rights of the affected victims. ${ }^{10}$ The inquiry procedure can be triggered by well-documented reports prepared by civil society organizations indicating grave or systematic extraterritorial violations by a State party, without actually requiring them to bear the weight of the whole procedure.

\section{Entry into force}

The OP-ICESCR was open for signature and ratification on 24 September 2009. The pace of ratification has been slow, but the numbers of ratifications is reaching the ten required for entry into force. As of 1 June 2012, 8 State parties have signed and ratified it: Ecuador, Mongolia, Spain, El Salvador, Argentina, Bolivia, Bosnia and Herzegovina and Slovakia. Another 32 countries have signed it.

\section{Recommended reading}

ALBUQUERQUE, C. de. Chronicle of an Announced Birth: The Coming into Life of the Optional Protocol to the International Covenant on Economic, Social and Cultural Rights - The Missing Piece of the International Bill of Human Rights. Human Rights Quarterly, v. 32, 2010.

COMMENTARY TO THE OPTIONAL PROTOCOL TO THE INTERNATIONAL COVENANT ON ECONOMIC, SOCIAL AND CULTURAL RIGHTS. International Commission of Jurists \& Inter-American Institute of Human Rights. Geneva, 2010.

\footnotetext{
${ }^{10}$ See Maastricht Principles on Extraterritorial Obligations of States in the Area of Economic, Social and Cultural Rights, principle 39 - stressing the need for States to take into account the victims' interest and opinion.
} 
COURTS AND THE LEGAL ENFORCEMENT OF ECONOMIC, SOCIAL AND CULTURAL RIGHTS. Comparative Experiences of Justiciability. International Commission of Jurists. Geneva, 2008.

LANGFORD, M. (Ed.). Social Rights Jurisprudence. Emerging Trends in International and Comparative Law. Cambridge: Cambridge University Press, 2010.

PERSPECTIVES on a New Complaint and Inquiry Procedure: the Optional Protocol to the International Covenant on Economic, Social and Cultural Rights. Nordic Journal of International Law, v. 27, n. 1, 2009.

SALOMON, Morgot E.; SEIDERMAN, Ian. Human Rights Norms for a Globalised World: The Maastricht Principles on the Obligations of States in the area of Economic, Social and Cultural Rights. Global Policy, v. 3, n. 4, p. 458-462, Nov. 2012.

VANDENBOGAERDE, A.; VANDENHOLE, W. The Optional Protocol to the International Covenant on Economic, Social and Cultural Rights: An Ex Ante Assessment of its Effectiveness in Light of the Drafting Process. Human Rights Law Review, v. 2, 2010.

Data da submissão: 23 de junho de 2015 Aceito em: 28 de junho de 2015 